\title{
A Qing Dynasty Astrologer's Predictions for the Future
}

清朝算命師對未來的占卜

\section{Collecting Materials*}

In January 2012, I was in Shanghai and naturally sought out several markets where I hoped to find research materials like those I have been collecting since 2004. Every Sunday, the Confucius temple in Shanghai holds a book fair in the main courtyard of the temple grounds, so that was an obvious place for me to explore. The majority of books for sale were produced in China after liberation in 1949, especially in the late 1970s and 1980s, when book publishing expanded after the Cultural Revolution concluded. Publications from the Cultural Revolution era seem to sell well in Shanghai and Beijing because they evoke nostalgia for a simpler time, especially among people who do not remember the period very well. ${ }^{1}$ Middlebrow novels, biographies of emperors or classical heroes, and translations into modern Chinese of classical

* I thank two colleagues at Suffolk University in Boston, Yang Xi 楊曦 and Zheng Da 鄭達, for their help and advice with this chapter. A version of this chapter was published as: "Collecting Research Materials in Shanghai: A Qing Dynasty Astrologer's Predictions for the Future," Journal of the Royal Asiatic Society China, n.s., 75, no. 1 (2013): 139-161. This version reflects additional study after that version was published, especially of fortunetelling methods.

1 My analysis of the people who buy materials from the Cultural Revolution period, from the vantage point of 2012, follows. Those now in their seventies and eighties who were adults and thus most strongly affected by the political activities during the Cultural Revolution, remember the period vividly. They do not want to buy these materials. Young people now in their teens or twenties do not remember the Cultural Revolution, so for them it has no special resonance, especially since the Chinese government does not allow a thorough discussion of those events. People in their forties to sixties, who were youngsters in the ten years from 1966 to 1976 , seem to have some nostalgia for those years, when life was simpler. Bad was bad and good was good. Every young child was dedicated to some public good, symbolized by wearing a red armband. If granny or your teacher cried, it was because they were still part of old China, when probably they had committed sins. At the book fairs in China I have attended, people in their forties to sixties are the most active in buying, selling, and collecting Cultural Revolution materials. The much younger and the much older tend to avoid browsing through those materials.

(C) RONALD SULESKI, 2018 | DOI:10.1163/9789004361034_007

This is an open access chapter distributed under the terms of the prevailing CC-BY-NC License at the time of publication. 
stories published since the 1980 s constituted a majority of the works on sale. Under a cold, cloudy, and threatening sky, the temple grounds were filled with rows of long tables covered with old books and magazines, rolled-up posters, stamp albums, and how-to books on cooking and travel. ${ }^{2}$

Happily, for me, one or two of the booksellers had small piles of old-fashioned books, sometimes bundled together in plastic bags. The materials I seek are often found in small bundles because that is how they are acquired by the urban booksellers. Merchants who buy old items, and sometimes those who collect trash from rural households, gather together the unwanted written materials they find and sell them to a network of used booksellers. Among many rural families, the old books once belonged to a grandfather or an elderly aunt and were kept in the bottom of a trunk or even on the shelves of a stable or workroom. It is not unusual to find signs that a goat or perhaps a rat has taken a bite out of the paper. The younger people, who cannot easily read the traditional complex characters and cannot understand the unpunctuated classical Chinese text, discard these materials after the death of their elderly relative.

Although the booksellers circulate old books toward the larger cities, which have more active book markets, the materials tend to circulate within the same geographic area. For example, the book markets in Beijing tend to have materials from regions in North and Northeast China, such as Liaoning and southern Jilin, Hebei, Shanxi, Shaanxi, and Shandong. In Shandong I found a number of old books in Ji'nan and Qufu, the birthplace of Confucius, all of which seem to have originated in Shandong. A few years earlier, books I found in Guilin all seem to have come from within Guangxi Province. It is exciting to find materials that can be identified as coming from the region where they were acquired.

On January 8, 2012, the day of my visit to the Shanghai Confucian Temple in Shanghai, I bought a number of interesting materials. The book that I describe in this chapter is a handwritten horoscope. It lacks a complete title page, so I call this work Astrologer's Predictions 1899, and it measures $9^{1 / 2}$ inches

2 In the flea markets and book-selling neighborhoods in China's cities, I have been surprised that each market contains several stands selling Cultural Revolution items. They are always filled to overflowing with those materials. When someone enters the shop hoping to sell the owner a piece of Cultural Revolution memorabilia, the item in question is carefully examined, often using a magnifying glass, to establish its authenticity. This is perhaps because the inexpensive items from those days are easy to reproduce, especially the Mao badges that often didn't show much wear or tear. 
$(24.1 \mathrm{~cm})$ high by $5^{1 / 4}$ inches $(23.5 \mathrm{~cm})$ wide, giving it the typical oblong shape of traditional Chinese books. The paper is handmade and unbleached, leaving it a yellowish or tan color, and it was cut using traditional methods as shown by the fuzzy upper and lower edges, rather than the sharp cuts that would have been made by a machine. Each sheet is folded in the middle, and the sheets are bound along the right-hand margin. The pages are bound with paper twine. Because of the low quality of the paper and the use of twine to bind the pages, I conclude that this book was intended to be used by the common people of the time. They would have accepted the matter-of-fact presentation of the fortuneteller's horoscope on inexpensive paper without any trappings of refinement in the calligraphy or artisanal workmanship in the paper and binding. They are exactly the people whose lives I want to better understand. ${ }^{3}$

This thin book has eleven sheets of paper, folded to make twenty-two individual pages counting the front cover as page 1. I purchased this book as part of a bundle of three works of similar size and composition. I paid RMB 200 (roughly us \$30) for all three, which I thought was slightly higher than the market price, but I did not feel like bargaining and thought that the seller would appreciate what I paid, and he did.

\section{An Astrologer's Predictions: The Mechanics}

The work I bought that pleasant Sunday morning was produced by a fortuneteller who was an astrologer. He used a solar calendar closely related to the twenty-four solar terms [ jieqi 節氣] and based on the heavenly stems and earthly branches [tiangan dizhi 天干地支] system of combining symbols to calculate periods of time. ${ }^{4}$ He combined that with a method of classifying the elements according to the ideas of yinyang and five elements [yinyang wuxing 陰陽五行] to produce calculations that also included the power of stars and the deities associated with them. He then might have compared his two sets of calculations, resulting in an august and accurate chart of fate [ziwei mingpan 紫薇命盤] (pp. 2 and 3 in the chaoben). That chart had all the elements laid out in a logical manner to predict the fate of its subject. The front cover of the book, which would have been a folded sheet that I would have numbered

3 In my collection at present are six other horoscopes organized in roughly the same style. The title pages(s) can contain some information about the person whose future is being predicted, but even that information usually omits the place name where the study was written. In many cases the first few pages have fallen away from over-use.

4 This system is explained in Chapter 9 and referenced in the notes below. 


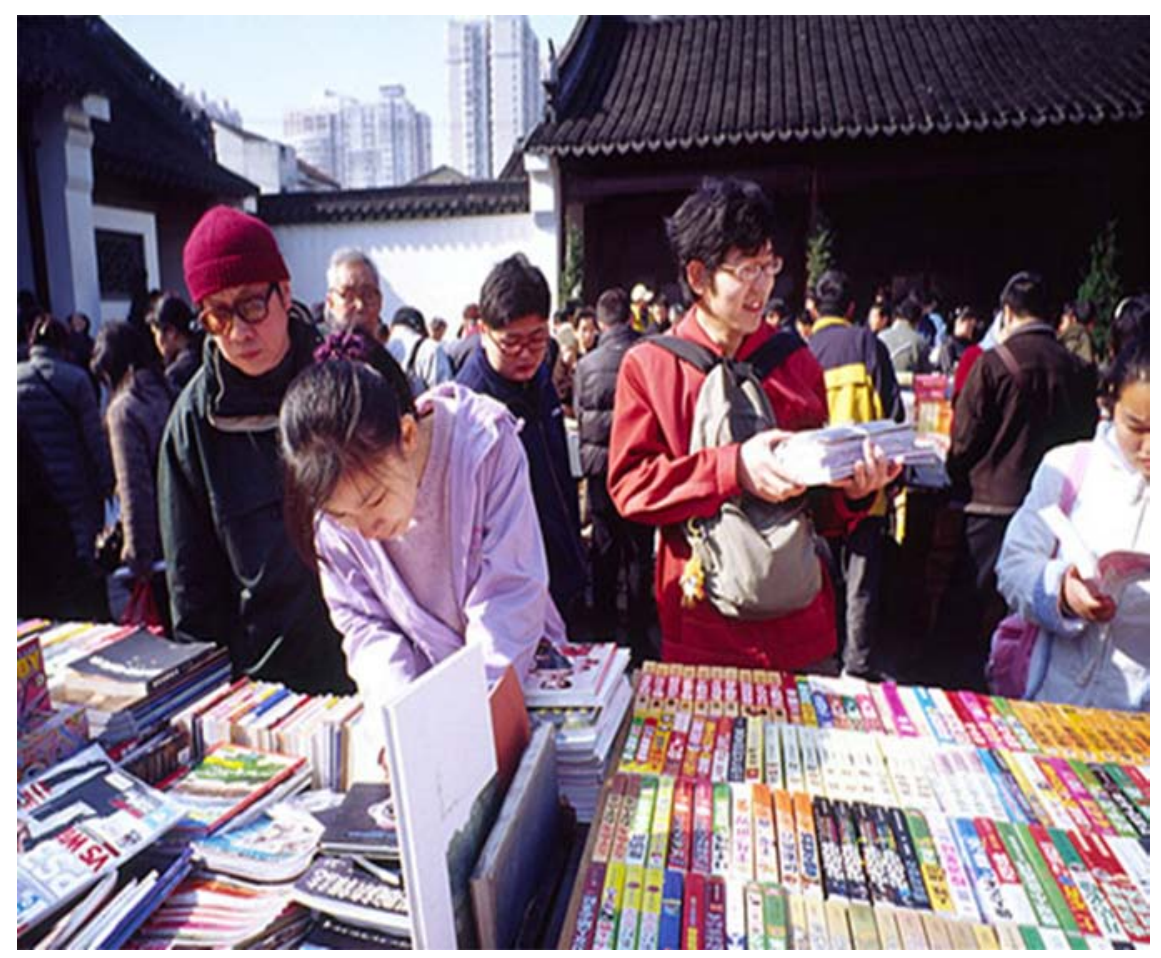

FIGURE 5.1

The Sunday Used BookMarket in Shanghai. The market is held at the Confucian Temple [Wenmiao 文廟]. It begins early (7:00AM) and ends early (about 3:00 PM). The photo was taken in 2012, when I bought some chaoben for sale under the eaves seen in the background.

PнОто BY AUTHOR

pages 1 and 2, had fallen off sometime in the past, so the first page I have was probably the first inside page of the actual book. (It ought to have been numbered page 3 , but I count it as page 1.) The front cover is the page most likely to be handled roughly, so it is not unusual for it to be missing from these bound works. Had it been intact, the front cover and inside page might have provided crucial information about the work, such as its title, the studio or temple name of the astrologer, and, on the inside cover, possibly the name of the client for whom the work was written or the name of the astrologer and the date the work was produced. Unfortunately, this particular chaoben had none of that information.

The phrase “year 14" [shisinian 十四年] is written horizontally across the top of page 1. I believe this is incomplete since it represents only the second-half of the original two-page title pages of the chaoben, and if we were able to read the entire phrase, it would be "twenty-fourth year of the Guangxu emperor," 


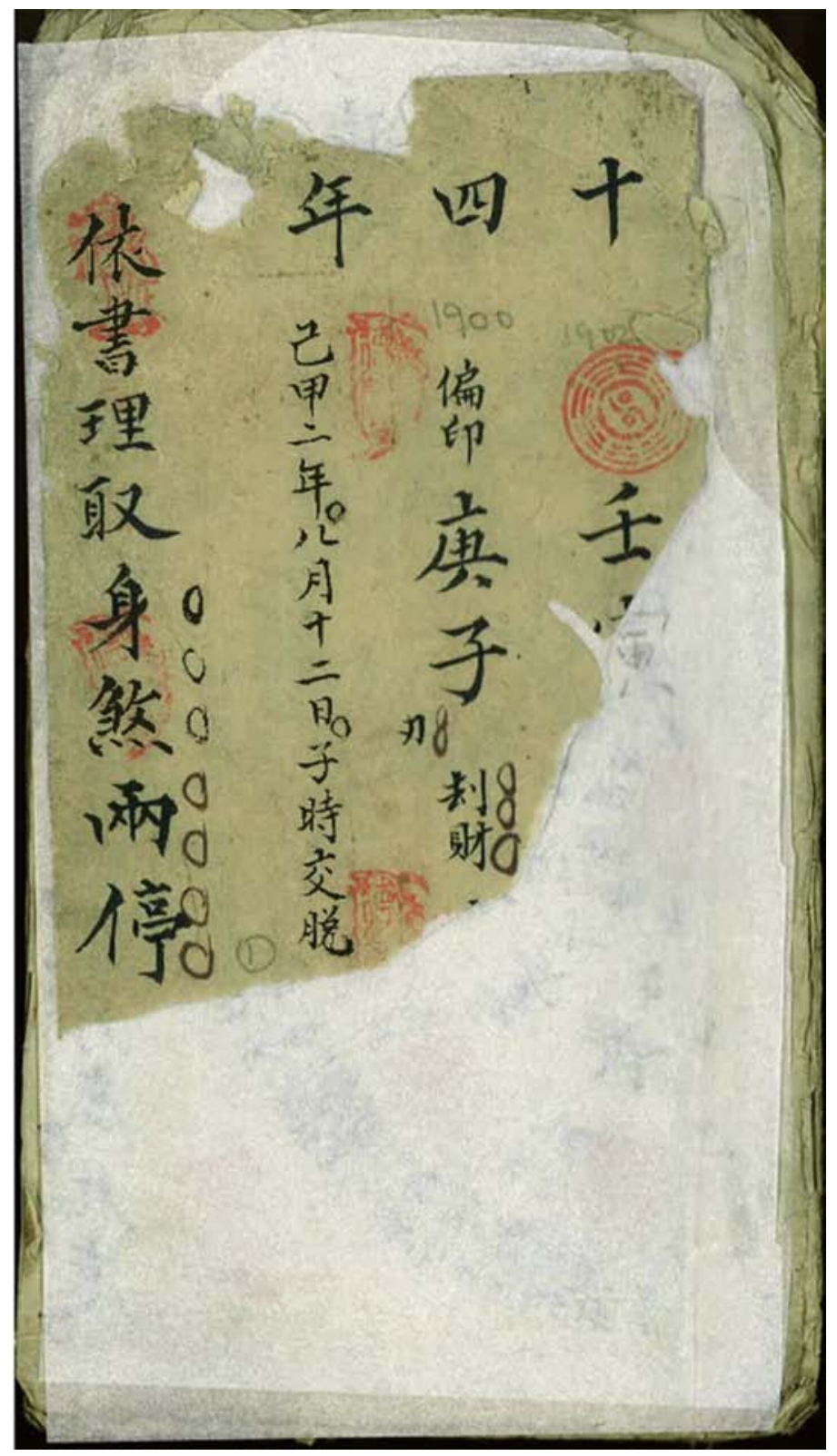

FIGURE 5.2

Astrologer, Cover. The actual cover had fallen off because of use, leaving only this half, originally tucked away inside the horoscope. Basic information about the horoscope had to be reconstructed from what remained. I surmised it was "Twenty-fourth year of the Guangxu emperor" [Guangxu 24 nian 光緒二十四年], that is, 1898, the year in which the subject of this horoscope was born.

PHOTO BY AUTHOR 
that is, 1898. It appears the subject of this horoscope was born late in the solar calendar year of 1898 , so that when the year changed a few months later, the infant gained a year and was suddenly listed as two years old. The fact that the subject is two years old in 1899 is given on page 8 .

The first remaining page of this chaoben presents a summary of the subject's major fate indicators. We begin at the right-hand margin and read the vertically written text leftward. This second half-page of the two-page front cover contains all sorts of truncated phrases. We find the term renyen 王寅, which, according to later information, represents the stem-branch combination of the day the subject was born. We then see the term gengzi 庚子, which represents the hour of the subject's birth. Above the gengzi is the term pianyin 偏印 [partial sign], which refers to the heavenly stem that follows it; below are the terms ren 刃 [blade] and jiecai 劫財 [unpredictable fortune], which refer to the earthly branch written just above it.

We then find the sentence jijia liangnian, bayue sihsiri, zishi jiaotuo 己甲 二年, 八月十二日, 子時交脫 [The changes in fortune will take place on August 12 of the $j i$ 己 and jia 甲 years, in the hour with a $z i$ 子 character]. In the Chinese calendar, each year is given a two-character designation based on the system of ten heavenly stems and twelve earthly branches, as mentioned above. Every few years, a year containing either the jia or the ji character appears, and the astrologer calculated that these would be years of a change in fortune for the subject of this book. According to this work, the subjects' fate would change gradually from the most negative to a bit less negative, to slightly positive, to the most positive. Then it begins to swing back the other way, with changes every six years. ${ }^{5}$

5 The method used by the fortuneteller to calculate our subject's fortune in this work seems to have involved a combination of two popular approaches. The first was to determine the basic yinyang symbols and their related signs under which the subject was born. The resultant eight hexagrams are based on the year, month, day, and hour of the subject's birth, which are the four pillars [sizhu 四柱] upon which one's life is founded. Each of these is connected to one of the calendrical calculations based on the traditional system of ten heavenly stems and twelve earthly branches. It is a system that indicates one's destiny in life, one's situation on any given day or month, and how to find the most successful occupation. The fortuneteller then linked these results to an astrological system, sometimes called Determining Fate [piming 批命], which depended on detailed knowledge of the Chinese symbolic calendar and astrology in which the influence of all the elements considered result in an outline of the subject's fate in the future. This explanation is modified from that found in http://en.wikipedia.org/wiki/ Chinese_fortune_telling/, accessed April 3, 2012. The basic information that a fortuneteller might take into account in constructing a horoscope is enough to fill a thick volume. See Yang 
The final phrase on page 1 is on the extreme left, Yishuliqu, shensha liangting 依書理取, 身繁兩停 [According to the theory of the documents, the body and the baleful force is of equivalent strength]. This might indicate the idea of the subject's ability to survive the vicissitudes of life. Indeed, the commentary for each year tends to evaluate the health of the subject and the dangers that might be encountered, part of the prediction of critical moments in the subject's future. According to the calculations of He Wumeng, this baby was born in the wuxu year [wuxu nian 戊戌年; i.e., 1898], in the guihai 癸亥 month (December), on the renyin 王寅 day of the fifth of the month, and at the gengzi 庚子 hour. The hour was from 11:0o pm to 1:oo am, between December 4 and December 5, so the child was born around midnight. ${ }^{6}$

By Chinese calculations, when the child was born, he was one year old. A few months later, the new year began, and the baby became two years old. Exactly how to calculate the subject's age seems to have bedeviled the astrologer, who was never sure what age to assign to his subject, as seen in the discussion below. I conclude that the horoscope was written in 1899, probably after the child had passed his 100-day anniversary, considered the time when mother and child could begin to meet other people beyond the family.

According to the astrologer, 1902 would be a crucial year for the young child whose fortune was being written and who would then be about age five, meaning he would be more likely to survive childhood illnesses and grow to adulthood. In 1902 the negative influences of the ji year in which the child was born would begin to give way slowly to the more positive influences of the next jia year, which would arrive in 1904. The horoscope for 1904 (p.10) lists the child as "seven and eight years old," which reflects the idea, I believe, of the child being given an additional year of age shortly after being born because of the quick arrival of the new lunar year.

This book begins its commentary in 1899, when the child was two years old. Detailed horoscopes are given beginning (on p. 8) with 1900 and continuing with year-by-year predictions until 1955, when the subject would have been

Chang 楊远 et al., ed., Zhuantong wenhua, quanshu 傳通文化, 全書 [Traditional Culture, Complete] (Harbin: Heilongiiang kexue zhishu chubanshe, 2012), 576.

6 For guidance in how this horoscope was calculated by the astrologer I benefited from the expertise of two scholars. He Wumeng 何無夢 at Duke University and Shao Yunfei 邵韻 霏 at the University of Chicago. Their understanding of the methods of fate prediction used and their clear explanations were of great help. He Wumeng calculated the date of birth of this child. On the power of the baleful stars in these calculations, see Ching-lang Hou (Hou Jinlang) 候錦郎, “The Chinese Belief in Baleful Stars," in Facets of Taoism: Essays in Chinese Religion, ed. Holmes Welch and Anna Sidel (New Haven: Yale University Press, 1979), 193-228. 


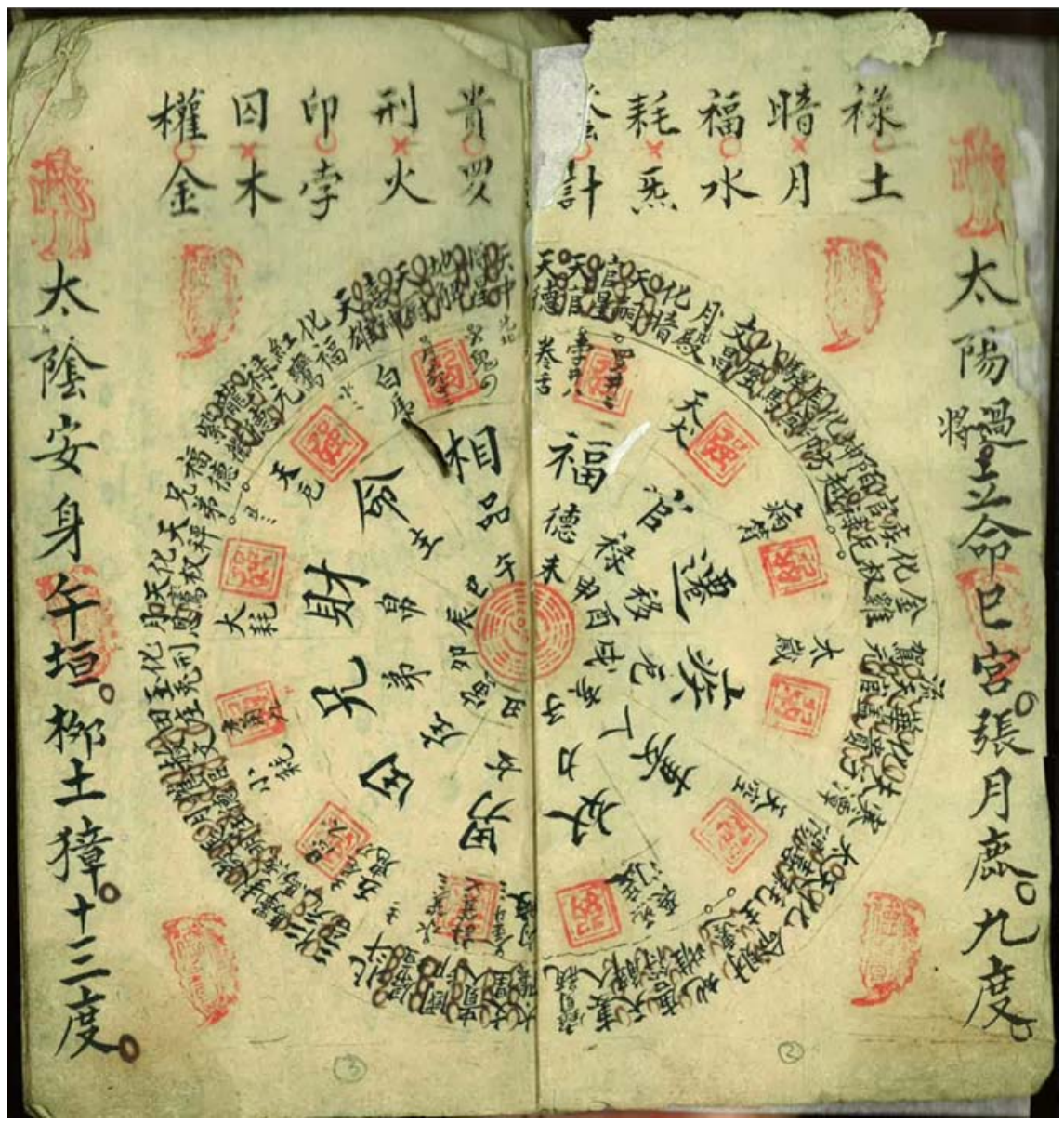

FIGURE 5.3

Astrologer, Pages 2 and 3, The Chart of Fate. Using all his calculations, the fortuneteller made an overall determination about how the stars and the elements would interact to influence the life of the subject of this horoscope. It was so colorful and intriguing that I bought it at the used book market. рното ву АUTHOR

fifty-eight years old. It is not unusual for a cycle of predictions to cover sixty years. The sixtieth year is known as a complete cycle [huanli 還曆], when all the possible combinations of the heavenly stems and earthly branches used to designate years have been completed, and the grand cycle begins again. The sixtieth-birthday celebration is of special importance because of this and might have called for a new set of predictions for the upcoming years. Therefore, ending the predictions at this point, when he was fifty-eight, did not mean that the subject would die but, rather, that a new set of predictions should be obtained. 
When I first glanced though the book at the temple fair, I was struck by the two-page spread (on pp. 2 and 3) of a large circle constructed by the fortuneteller to be used as a guide to determining the subject's fortune. The circle, called the chart of fate [mingpan 命盤], has five concentric rings. In the center of this circle, the "hub" is a listing of the eight trigrams, which form the basis of traditional Chinese philosophy. The trigrams are based on eight sets of three lines each, with unbroken lines being elements of yang 陽, roughly considered positive elements, while broken lines are said to represent yin 陰, which are negative aspects. But only two of the trigrams represent pure yin or pure yang. Rather, most are combinations of both. It is not clear whether these trigrams are meant to apply precisely to the reading of the elements in the circle or are more a decoration for the center of the ring.

The innermost ring contains the twelve earthly stems that appear in the year designations of the lunar calendar. For example, to read one of the "spokes" in the ring, the reader can locate the designation shen 申 in the innermost circle that constitutes ring 1 (roughly at the two o'clock position). Proceeding outward from ring 1, rings 2 and 3 is a larger box with the term guanlu 官祿 [official fortune]. This indicates good fortune in one's career or occupation. In traditional Chinese thinking, to achieve an official position with government rank was a sure path to good income and social status, so the phrase has only positive connotations. Ring 4 has a red seal inside this box that says qiang 強 [strong], meaning that years with this stem in their designation will be years of good fortune. Also in that box is written tianquan 天大 or tiangou 天狗 [heavenly dog], which refers to the negative element, a star, that will need to be overcome. Folk beliefs in Chinese astrology say that the heavenly dog must be beaten back in order for the good fortune to take place. Conversely, the heavenly dog was seen by some as a protective star. ${ }^{7}$

7 This is only one of several methods of calculating fortunes. For explanations of some of these methods, see Peter Shen, The Traditional Art of Chinese Fortune Reading (Selangor Darul Ehsan, Malaysia: Pelanduk Publications, 1998); Richard J. Smith, Fortune-Tellers and Philosophers: Divination in Traditional Chinese Society (Boulder: Westview Press, 1991). Many of the elements taken into account by the astrologer are enumerated in Wu Kang 吳康, ed., Zhonghua shenmi wenhua cidian 中華神秘文化辭典 [Dictionary of China's Mysterious Culture] (Haikou: Hainan chubanshe, 2002), esp. 493-539. An example of a chart of fate similar to the one in the astrologer's book discussed in this chapter appears in Yabuuchi Kiyoshi 數 内清, Chūgoku no tenmon rekihō 中国の天文暦法 [Chinese Astrological Calendars] (Tokyo: Heibonsha, 1969), 19o. It is based on a Tang-dynasty formula developed by Zheng Chuhui 鄭 處誨 an official who received a jinshi 進士 [presented scholar] degree in 834. His appoint- 
The overall positive aspects of this stem designation are listed in the outermost ring 5 , which gives a number of influences and star deities that preside within this shen designation. The influential element is huayin 化印 [using the seal]. This is a positive sign because the seal on a document can produce good results, meaning that decisions will be made and the good fortune will come into effect. Next are several star deities: the evening star Venus [Changgeng 長 庚], when seen in the West is brighter than the others; courier horses [yima 驛馬], means this star has the power to effect change; the god of constellations [bazuo 八座] brings brightness and clarity; the god of literature [Wenchang 文 昌], officially known as Wenchang dijun 文昌帝君, brings a successful professional career. Thus by identifying the earthly stem in each year designation in the innermost ring, the subject of this study can read outward to discover which forces will determine his fate for the year with the shen designation. ${ }^{8}$

The other decorations are the various red seals and stamps left by the fortuneteller, such as the seal for "strong" mentioned above. In this chart, some rings are marked ruo 弱 [weak]. Some seals are in the form of a cartoon-like scholar figure. More important for our purposes are the seals in the shape of a leaf on the pages with the chart and on every page over the year prediction. This seal has the term guangde 廣德 [wide virtue]. This might be the studio name or the trademark of the astrologer who prepared this set of predictions. Such trademarks used in this manner were not registered or controlled, so it is almost impossible to trace it back to its owner.

\section{An Astrologer's Predictions: Telling the Future}

This person is presumed to be male because commissioning an astrologer to prepare this prediction of the future must have been expensive and (unfortunately) few families would consider their daughter's future to be of sufficient import to predict. Her future would be tied to that of the family of her betrothed as soon as she joined his household. Most likely, the subject of this prediction

ments show a steady progression of high bureaucratic office, first at the national level at the Imperial Court, and later as a representative of the central government in regional areas.

8 Explanations of many of the symbols used by the astrologer are in E.T.C. Werner, A Dictionary of Chinese Mythology (Taipei: Cave Book, 1961). Highly detailed instructions for constructing a chart of fate are in "Ziwei mingpan 紫薇命盤 [August and Accurate Chart of Fate]," http:// baike.baidu.com/view/6o66456.htm, accessed April 3, 2012. These symbols are also discussed in Wu, Zhonghua shenmi wenhua cidian. 


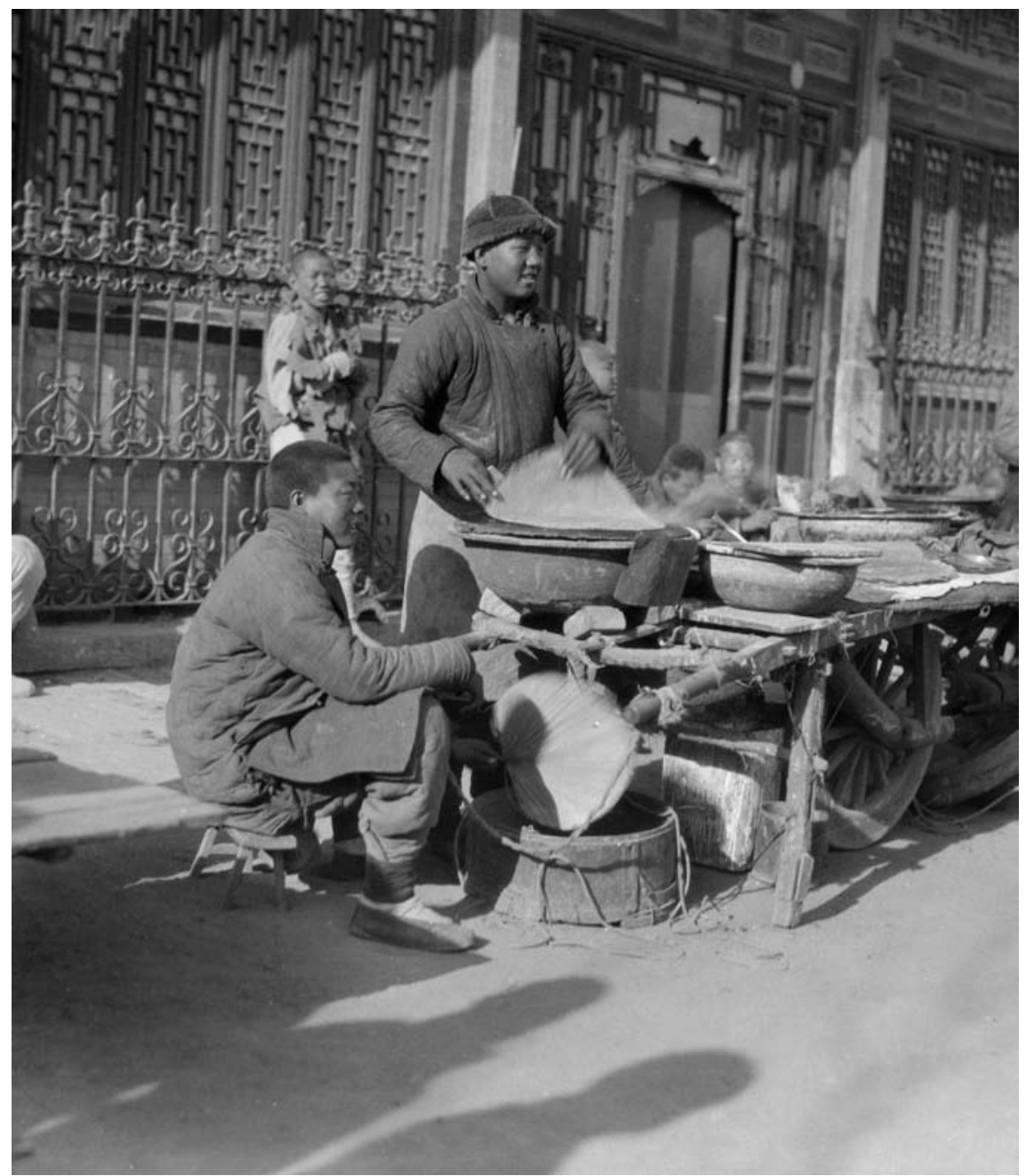

FIGURE 5.4

Baking Pancakes. Flatcakes, or pancakes made with wheat flour, are especially popular in Manchuria and North China, where wheat is widely grown. They are usually fried in oil, flavored with onions, and possibly filled with ground meat. Fried egg pancakes [jian bing 煎餅], for instance, are a popular breakfast food. The photo was taken about 1918 in Beijing.

SIDNEY D. GAMBLE PHOTOGRAPHS, DAVID M. RUBENSTEIN RARE BOOK \& MANUSCRIPT LIBRARY, DUKE LIBRARY 
would be expected to take over the family business or eventually control its assets, so his probable future was important to the family, and the prediction was no doubt eagerly read by all adults in his household.

The astrologer most likely considered all the signs of this child-such as the year, month, day, and time of day of the child's birth — and then compiled the astrological chart (pp. 2-3). He then prepared an overview of the child's strengths and general prognosis (pp. 4-5). He wrote that the child was born under the sign of water [ren 1 ]. This indicates bounty, but, if it is not controlled, water can overwhelm with its excess. Fortunately, there is also the earth element [ $w u$ 戊] in his set of heavenly and earthly signs for the child since the year of birth (1898) was a wuxu year, and earth is able to control water. The good combination of elements means that the child can even "control the flooding of the three rivers" [kesai sanjiang zhi yi 可塞三江之溢]. This strong position allowed the astrologer to anticipate that this child would be successful regardless of whether he undertakes an official career [dang guan 當官] or goes into business [cong shang 從商]. As a youth, the boy is predicted to be "intelligent and with a delicate beauty" [congming junxiu 聰明俊秀] and, as an adult, to “stand out from the crowd" [wanzhong chaoqun 萬眾超群]. ${ }^{9}$

The astrologer's conclusion was that the boy would find his fortune, not in an official career, but in the world of business. It seems likely that the astrological chart led the fortuneteller to opine that this child would be embroiled in some struggles in life ("gathering the wind and the clouds" [ fengyun zhihui 風雲 之會]) but would be able to overcome these difficulties. Both parents were projected to live long and fruitful lives, and the family was expected to flourish.

\section{Year-by-Year Predictions}

Year-by-year predictions on this subject are on pages 8-21. In most cases, the astrologer used phrases from poetry or analogies from nature to convey his meaning. For example, for 19o6, when the boy would be nine years old (on p. 10), the astrologer wrote, zhinian fengchui songxiazi yuda xingfeihua 只年,

9 Traditional Chinese beliefs considered all forces in the natural and cosmological worlds interdependent. The stars in the skies became associated with Daoist deities, who could determine the fate of humans living on earth. This highly integrated concept, based on an examination of classical texts, is set forth in Lu Xishen 呂錫深, Daojiao yu minzu xingge 道 教與民族性格 [Daoism and National Character] (Changsha: Hunan University Press, 1996). 


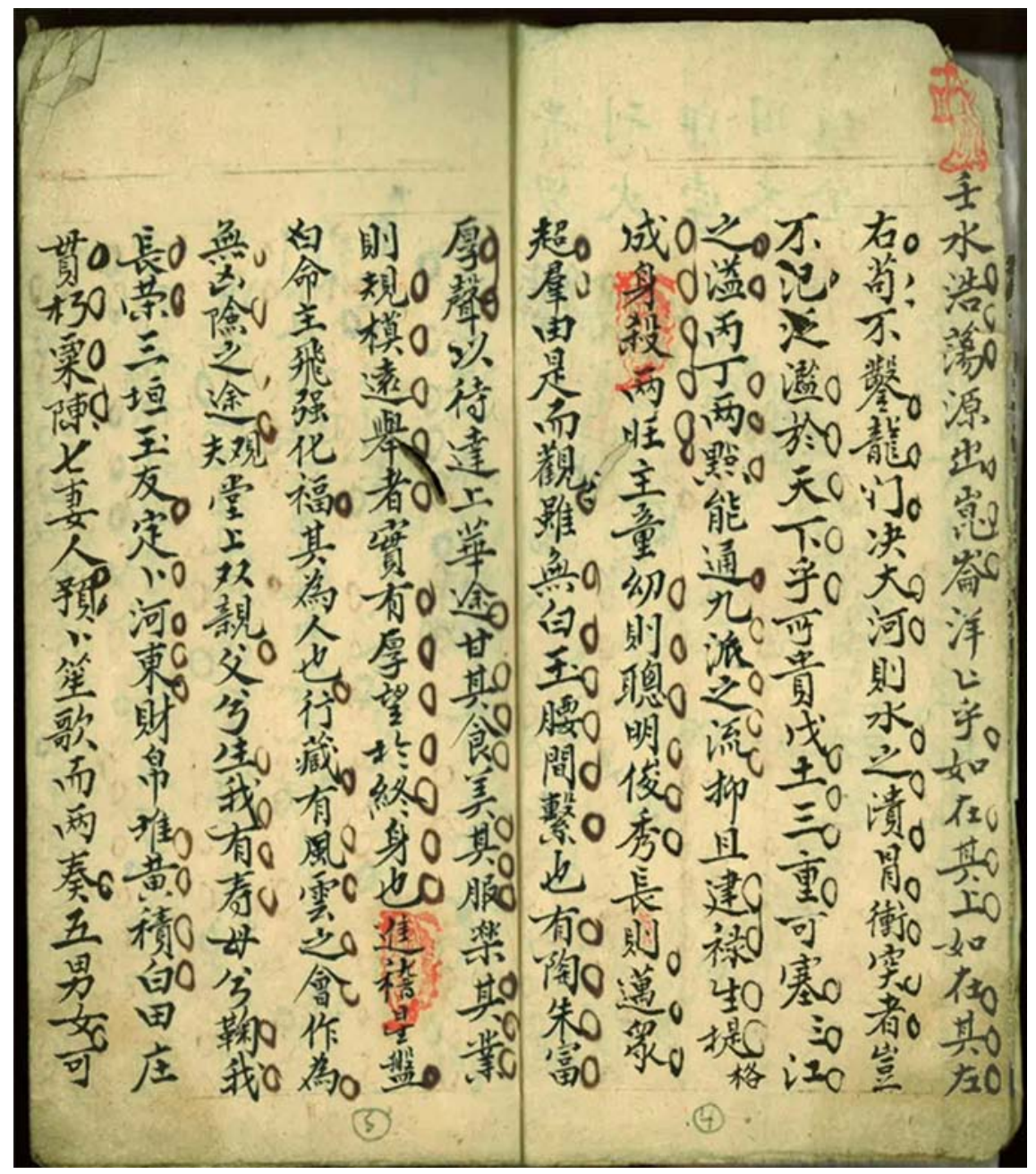

FIGURE 5.5

Astrologer, Pages 4 and 5, The Character of the Child. On these beginning pages, the astrologer said the baby had been born under the water sign, but among the elements influencing his fate was also the influence of the earth, with the result of a good balance of elements. The astrologer wrote that this child could be expected to be successful regardless of whether he undertakes an official career [dang guan 當官] or goes into business [cong shang 從商].

Pното BY AUTHOR

風吹松下子, 雨打杏飛花 [In this year, the winds cause the pines to bend and the apricots to fall], the meaning of which indicates a natural progression of the seasons. For 1935 and 1936, when the subject would be thirty-eight and thirtynine years old, respectively (p. 17), the astrologer advised that, when helping others, he should be careful how he helped them so as to avoid later difficulties. 


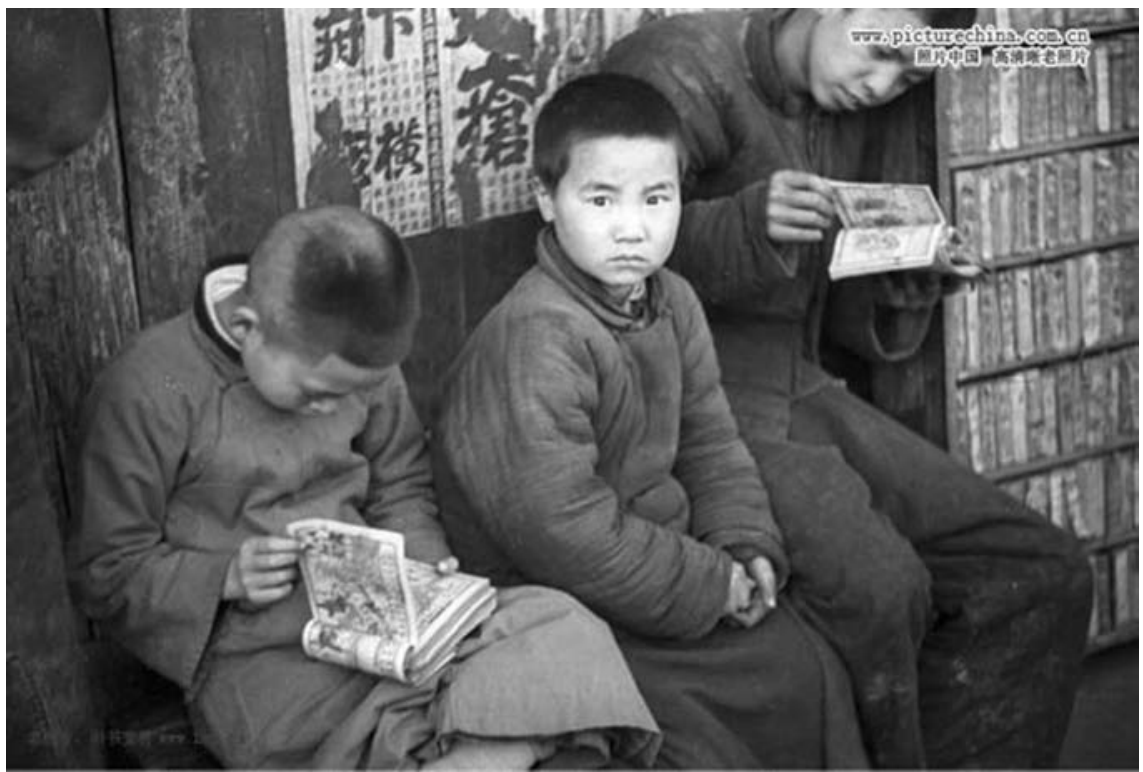

FIGURE 5.6

Poor Boys Reading. Until the 196os, poor children in Asia who wanted to read comic books or children's books, could approach a street-side book stall, where they could pay a few coppers [qian 錢] to "rent" a bookfor a short time. Ideally the boy discussed in this horoscope would be inclined to practice reading when he had free time, even if his family did not have many books at home. Photo of boys reading rented books outdoors in Shanghai in the late 1930 .

FROM THE AMERICAN GEOGRAPHICAL SOCIETY LIBRARY, UNIVERSITY OF WISCONSINMILWAUKEE LIBRARIES

He expressed this by using the phrases gejiang ren, jiaodu 隔江人, 叫渡 [People separated by a river, call out to cross], and chuanren yao xiaoxin 船人要小心 [People on boats must exercise caution].

The emphasis the astrologer placed on analogies related to water was striking and was likely because the child was born under the water element. But it could also have been because this family was engaged in the river and coastal shipping trade along the east-central coast of China, south of Shanghai near Wenzhou 溫州. This idea seemed evident from the analogy for 1940, when the subject would be forty-three years old (p. 18). The fortuneteller indicated this would not be a good year for the subject, writing, ming Wenzhou dafeng hanqin [illegible character] lei 苦溫州大颱漢葠 [illegible character] 雷 [it will be as if a bad typhoon strikes Wenzhou with flashing thunder and lightning]. I then began to notice the frequent use of water and river analogies, such as this phrase for the year that the subject would be forty-nine years old (p. 19): shunfeng jiangshang, youyangfan; buliao jiangxin you shitan ye 順風, 江上, 有揚帆; 


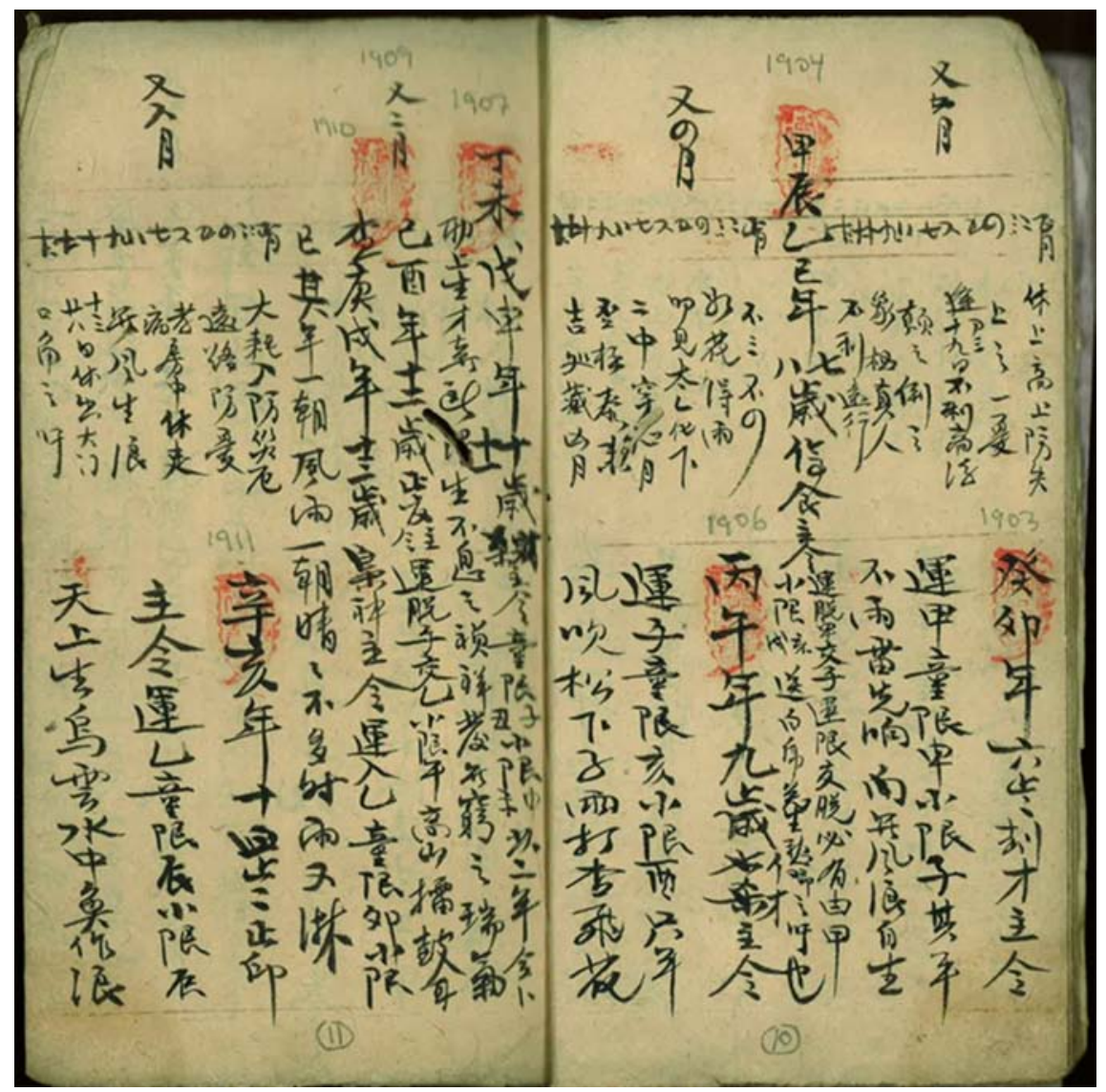

FIGURE 5.7

Astrologer, Pages 10 and 11, as the Boy Grows. On page 10, the fortuneteller wrote about the boy in 1906 when he was nine years old: "In this year the winds cause the pines to bend and the apricots to fall” [Zhinian fengchui songxiazi yuda xingfeihua 只年, 風吹松下子, 雨打杏飛花], the meaning of which indicates a natural progression of the seasons. When the boy was young, his life was one of developing his character and his skills.

Рното BY AUTHOR

不料, 江心, 有石灘也 [for good sailing in the river we hoist a sail, but if not prepared might hit a submerged rock]. The fortuneteller was giving a warning to be on the lookout for unseen danger. ${ }^{10}$

10 If we remove the final character 也 ye from this phrase, we see that it rhymes [ fan 帆, tan 灘]. 




FIGURE 5.8

Astrologer, Pages 16 and 17, Adult Interactions. On page 17, for 1935 and 1936, when the subject would be thirty-eight and thirty-nine nine years old, the astrologer advised that when helping others, one had to be careful in how they are helped so as to avoid later difficulties. He expressed this by using the phrases "People separated by a river, call out to cross" [Gejiang ren jiaodu 隔江人, 叫 渡] and “People on boats must exercise caution” [Chuanren yaoxiaoxin 船人, 要小心]. Note the continuing use of water analogies.

Pното BY AUTHOR

Wenzhou is a well-known port city, and its inhabitants are known as entrepreneurial people who not only engage in trade but also are willing to travel far afield for the sake of their business. Water and costal shipping play a critical role in the fortunes of the city and its people. The mighty $\mathrm{Ou}$ 甌 River, the largest in the region, flows into the city from the west and is joined by the Nanxi 楠 溪 River flowing down from the north. Wenzhou Bay dominates the city to its 


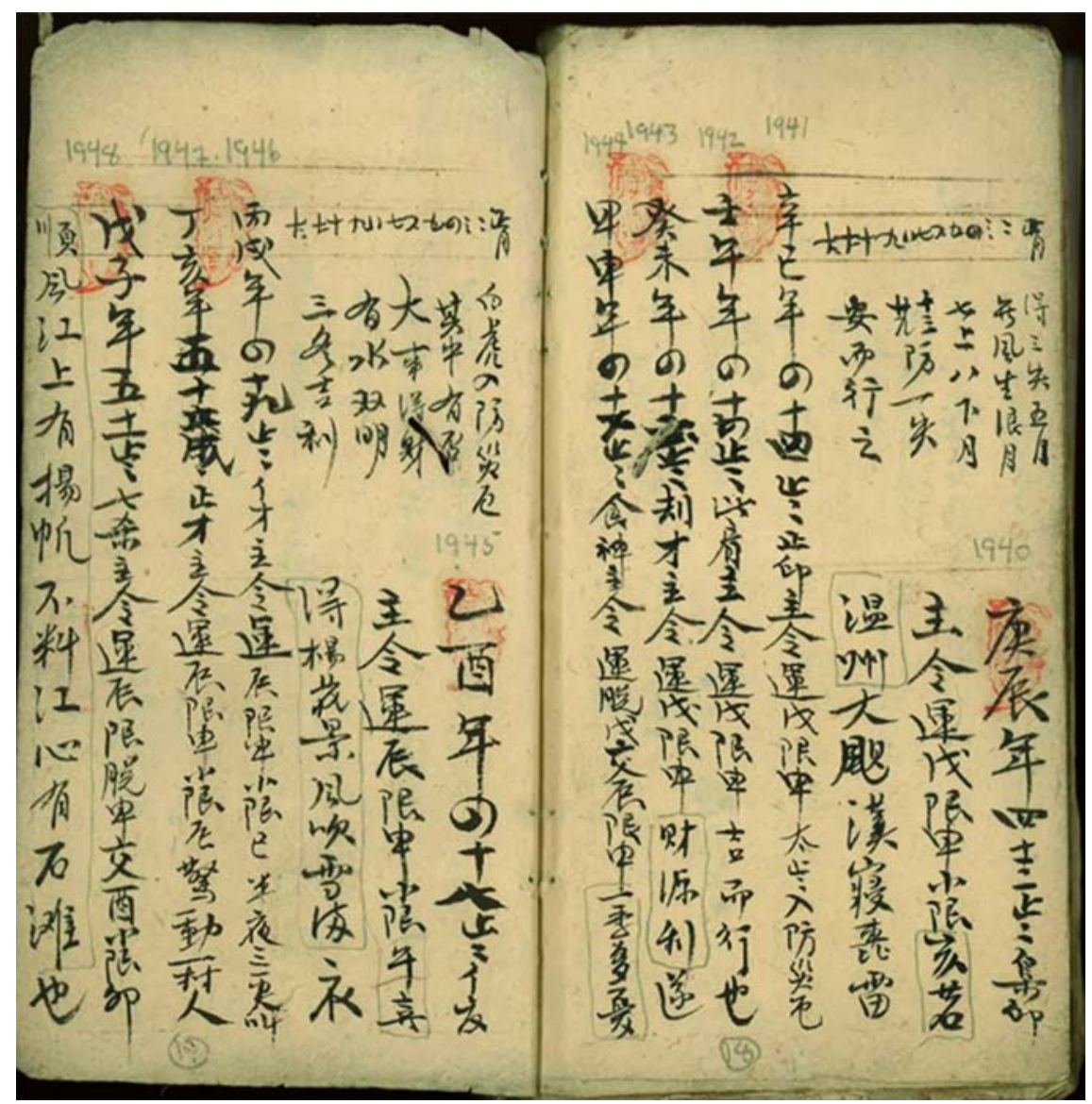

FIGURE 5.9

Astrologer, Pages 18 and 19, Large Forces Enter His Life. The early 1940 s are covered on page 18. In 1940, when the Japanese forces occupied Shanghai, our subject was forty-three years old. The fortuneteller indicated this would not be a good year for the subject, writing: "It will be as if a bad typhoon strikes Wenzhou with flashing thunder and lightning" [Ming Wenzhou dafeng hanqin $\mathrm{x}$ lei 茗溫州大颱漢寢口雷]. This phrase suggests the subject was in Wenzhou, a few hundred miles south of Shanghai, and indicates that his family was engaged in river-borne and coastal trade by ship.

PHOTO BY AUTHOR

east and greatly affects its weather. Could these be the "three rivers" poetically referred to by the astrologer? Moreover, Wenzhou is in the path of many powerful typhoons that spawn in the South Pacific. Thus the astrologer's reference to typhoons at Wenzhou would not have been lost on any resident of the city. This strong connection in the region to waterborne shipping is indication that the subject's family was engaged in business, possibly in river and coastal shipping. 


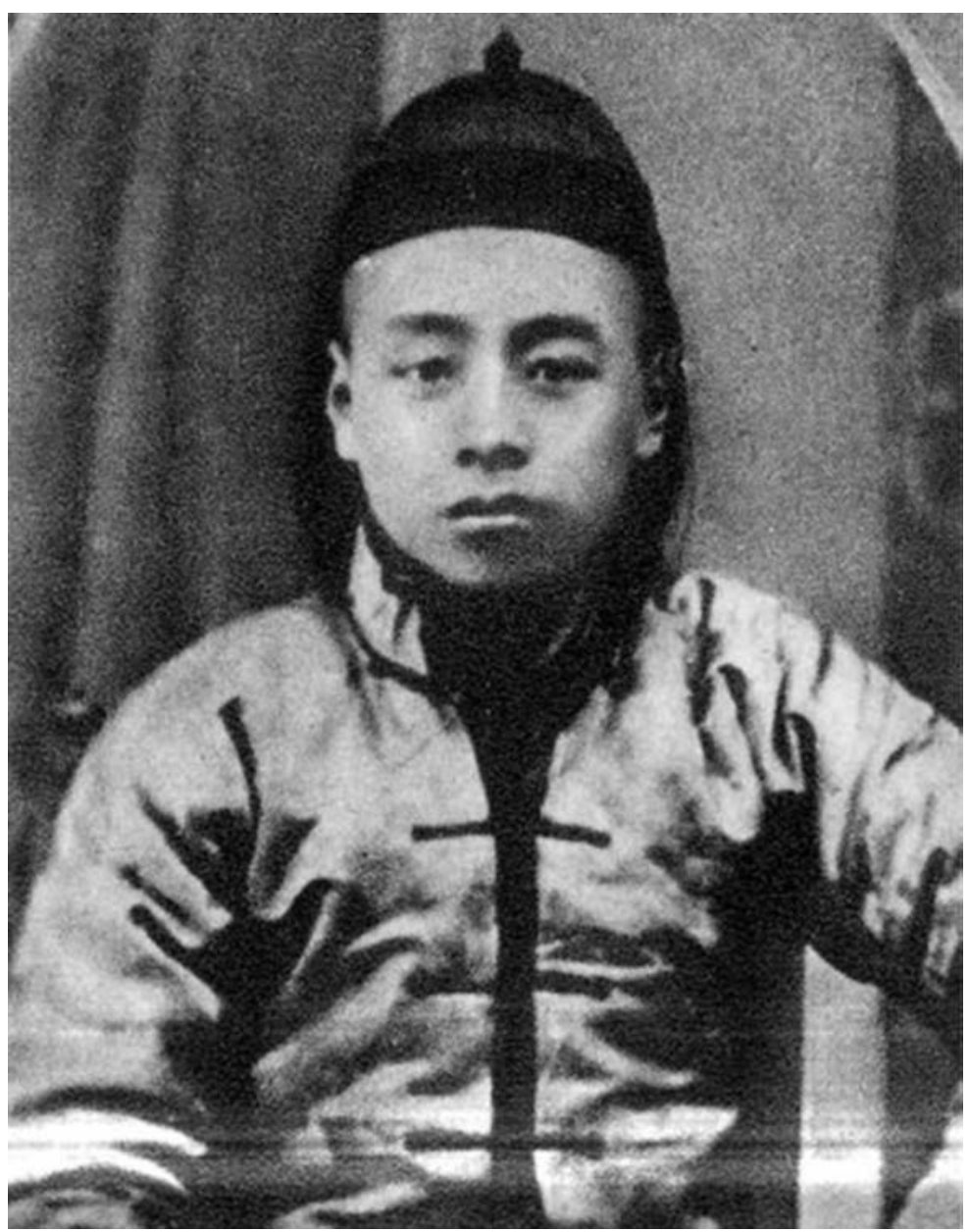

FIGURE 5.10

Zhou Enlai as a Boy of Twelve. My point is that the $19 n$ Revolution in China that saw the fall of the old government and establishment of the Republic of China, did not affect families or children who were away from the areas where heavy fighting took place. In 1911 Zhou Enlai 周恩來, who later served as premier of the People's Republic from 1949 until his death in 1976, was a student living with relatives and studying in Shenyang 潘陽. He was the same age as the subject of this horoscope, who I assume was in the Wenzhou area and was not directly in the events of 1911. Thus the prosaic predications made by the astrologer for our subject's boyhood years.

WEB РНОTO 


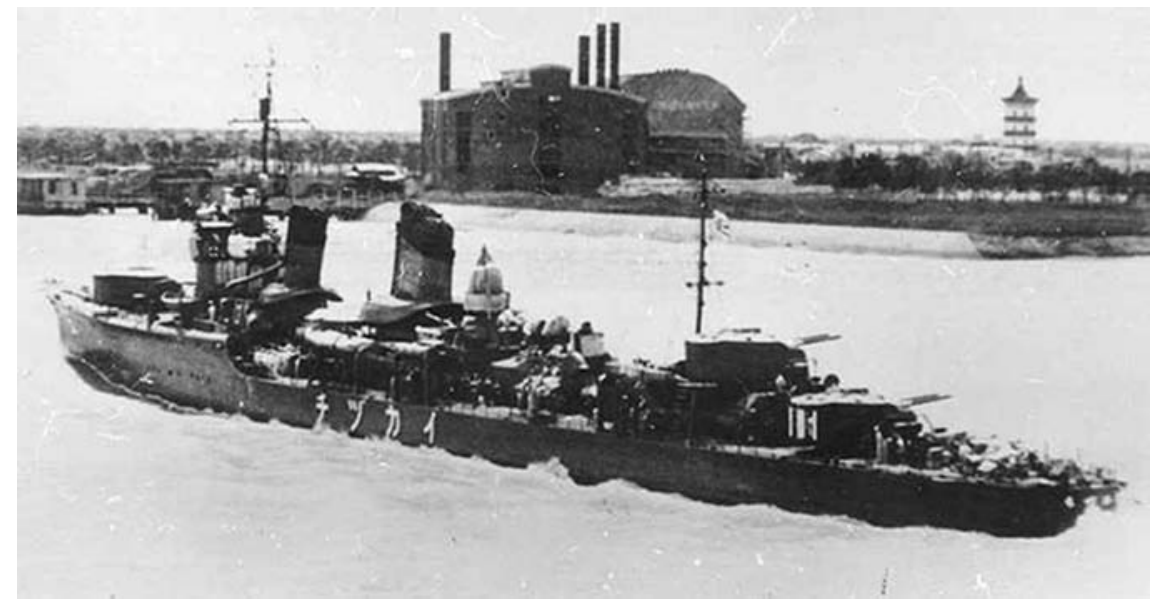

FIGURE 5.11

Japanese Destroyer off the China Coast. Photo shows the Japanese destroyer Ikazuchi いかず ち雷 off the China coast in the 1940s. Its guns are pointed landward toward the Chinese coastal settlements. During World War II, the subject of the horoscope may have found a way to work with the Japanese in the exchange of smuggled goods along the coast between the Japanese-controlled areas and the "Free China" areas held by the Nationalists [Guomindang 國民黨].

WEВ РНОто

By all accounts, Wenzhou society evolved differently from that in most other parts of China. Because of the many mountains surrounding the city, overland transportation to the inland areas, such as the provincial capital at Hangzhou, was difficult and not highly developed. A train line from Wenzhou to Hangzhou was only opened in 1993 ! This made river and coastal transport quite important. Wenzhou residents were willing to travel as much as they needed in order to find work and secure an income, often in river and coastal shipping. They had an entrepreneurial spirit, and the businesses they formed were generally small in scale, organized with funds and labor from their family. Local government influence was not strong, allowing the people in Wenzhou to exercise ingenuity in their social and commercial matters. It is logical therefore to suggest that the male whose life is covered in this horoscope came from a family involved in small-scale shipping and trading. ${ }^{11}$

11 These characteristics of Wenzhou residents were so pronounced by the 1980s and 199os, when commercial and economic development was encouraged by the Chinese government, that economists refer to it as the Wenzhou model, a complex of local values and the resultant pattern of commercial development. These characteristics are elaborated on in Jianjun Zhang, "State Power, Elite Relations, and The Politics of Privatization in China's Rural Industry: Different Approaches in Two Regions," Asian Survey, 48, no. 2 (2008). See 


\section{Were the Predictions Accurate?}

When these predictions were prepared in 1899 for the newborn child, no one knew whether they would be accurate. Given the general and allusive nature of each prediction, the forecasts could be interpreted to fit a variety of circumstances. Because we do not even know the identity of the subject of these predictions, we have no way of knowing whether they were accurate or useful for the subject of the study. However, we do know something of the history experienced by the people who lived in and near Wenzhou during that half-century, so it is possible to judge, in a very general way, the accuracy of the predictions. For example, we know that in 1911 a series of uprisings broke out that culminated in the collapse of the Qing dynasty in 1912 and the establishment of the Republic of China. At that time, our subject was thirteen and fourteen sui 歲 ("years old" by traditional counting) and seems not to have been affected in any particular way by these events. Many Chinese were not directly or immediately affected by that great political change. Our subject's fortune for 1912 does not indicate any disruption of normal life.

The Japanese occupation of parts of China that began in earnest in 1937 affected a greater number of Chinese. However, the predictions for our subject's life during the war years show only the usual pattern of swings from good to bad, but not any traumatic events. This made me look at Wenzhou during the war years in order to try to judge how severely our subject's life might have been affected. Japanese military forces occupied Shanghai, about 300 miles north of Wenzhou, in 1937, but they never occupied or fully controlled Wenzhou. From 1938 to 1940, they heavily bombed Wenzhou in an effort to disrupt the river traffic there and to blockade the port with sunken ships. They patrolled the coast and had a garrison on one of the islands in Wenzhou Bay. ${ }^{12}$

But, as the war continued, shipping through Wenzhou flourished, because the Japanese needed some of the goods that could be taken from the Chinese countryside to the city, and even Chinese forces in the countryside could use goods obtained in Shanghai. Wenzhou was on the border between

also the concluding section of Bin (Henry) Wu and Wang Huiyao, "Going Global of Chinese Private Enterprises: Wenzhounese Model and Its Impact on Home Development" (paper presented at the Globalization of Chinese Enterprises Conference, Harvard University, October 9-10, 2008), http://www.ccg.org.cn/ccg/ccgen/2011/0721/59o.html, accessed April 12, 2012.

12 From 1938 to 1942 the Japanese Imperial Navy conducted air raids on Wenzhou harbor in order to disrupt shipping, to sink ships and blockade the harbor, and to assert their ability to do so. 




FIGURE 5.12

Three-Antis Political Campaign. This political campaign was directed against people who ran small to medium-size businesses. They criticized business owners as capitalists who harmed the proletariat workers. In this photo, a man who ran a pharmacy is being denounced and criticized by a Chinese Communist Party cadre. The photo was taken in Guangzhou 廣州.

WEB РнОто

Japanese-occupied eastern China and the unoccupied inland regions nominally under the control of the Guomindang 國民黨 [Nationalist] forces of "Free China." Smuggling was brisk, involving both the Chinese Nationalist forces and the Japanese military. Much of the smuggling was carried out by Chinese (perhaps by our subject?) sailing small wooden boats along the coast like those used in the river trade. Some of the Chinese smugglers in the Wenzhou area earned high income from the trade. Perhaps, given that context, the fortuneteller's predictions for the war years should not be surprising. For example, in 1942 our subject was forty-four years old, and his fortune was predicted to be generally good because all the heavenly forces aligned well (p. 18). ${ }^{13}$

13 An overview of Wenzhou during World War II and the flourishing of river and coastal smuggling that brought large fortunes to some Chinese in the area is given in R. Keith 
The event that spared virtually no Chinese was the establishment of the People's Republic of China in 1949. At that time, the land reform campaigns against property owners to redistribute their wealth to landless peasants had already started in areas under communist control. The Five-Antis [Wufan 五 反] campaign was launched in January $195^{2}$ against business owners, who were classified as being part of the exploiting capitalist and petty-bourgeois class. If the subject of these predictions was the son of a small business owner who may have had some boats and warehouses in order to engage in river and coastal shipping near Wenzhou, then the family was surely the target of criticism by Chinese Communist Party (CCP) cadres and the masses. Could the astrologer writing at the turn of the century fifty years earlier have foreseen these events? We can look at the predictions for 1952 to 1955 (p. 21).

For 1952, when the subject was fifty-five years old and the anti-business campaigns in China were at their height, the subject's fortune was given as zhinian, yunzhong guanxingdou; mengli, dakongquan 只年, 雲中觀星斗; 夢裡, 打空拳 [This is a year in which nothing can be accomplished, as if one sits on the clouds looking at the stars or raises one's fist while in a dream]. We know from historical records that those accused by the authorities were given no opportunity to defend themselves or to justify their years of work to build a business, and justice was defined by the authorities in charge. The subject's position as a scapegoat and target of continuous criticism seems to be reflected in this prediction. ${ }^{14}$

Schoppa, In a Sea of Bitterness; Refugees during the Sino-Japanese War (Cambridge, MA: Harvard University Press, 2011), 263-272.

14 The Five Antis campaign was designed to target the capitalist class. The CCP had very vague guidelines as to who could be charged, and the campaign became an all-out war against the bourgeoisie in China. An estimated 20,ooo cadres and 6,ooo trained workers began spying on the business affairs of their fellow citizens. The media encouraged compliance with the government's policies. As many as 15,00o trained propagandists were working in Shanghai by late 1951. In February 1952, parades of anti-capitalist activists went door-to-door to visit business leaders, creating immense psychological pressure. Shanghai ward offices were set up to receive criticism letters from any employee. Some big companies voluntarily offered 1,00o confessions a day to try to protect themselves from the government. The victims of the Antis campaigns (including the earlier Three Antis campaign against government cadres and bureaucratic waste) were mostly terrified and humiliated, some were killed, and others were sent to labor camps around China. Hundreds of thousands of people committed suicide (though it is debatable whether many of them did so voluntarily) as a direct result of these campaigns. Eventually, the CCP revealed that it would no longer protect private business and that Chinese capitalists would receive 


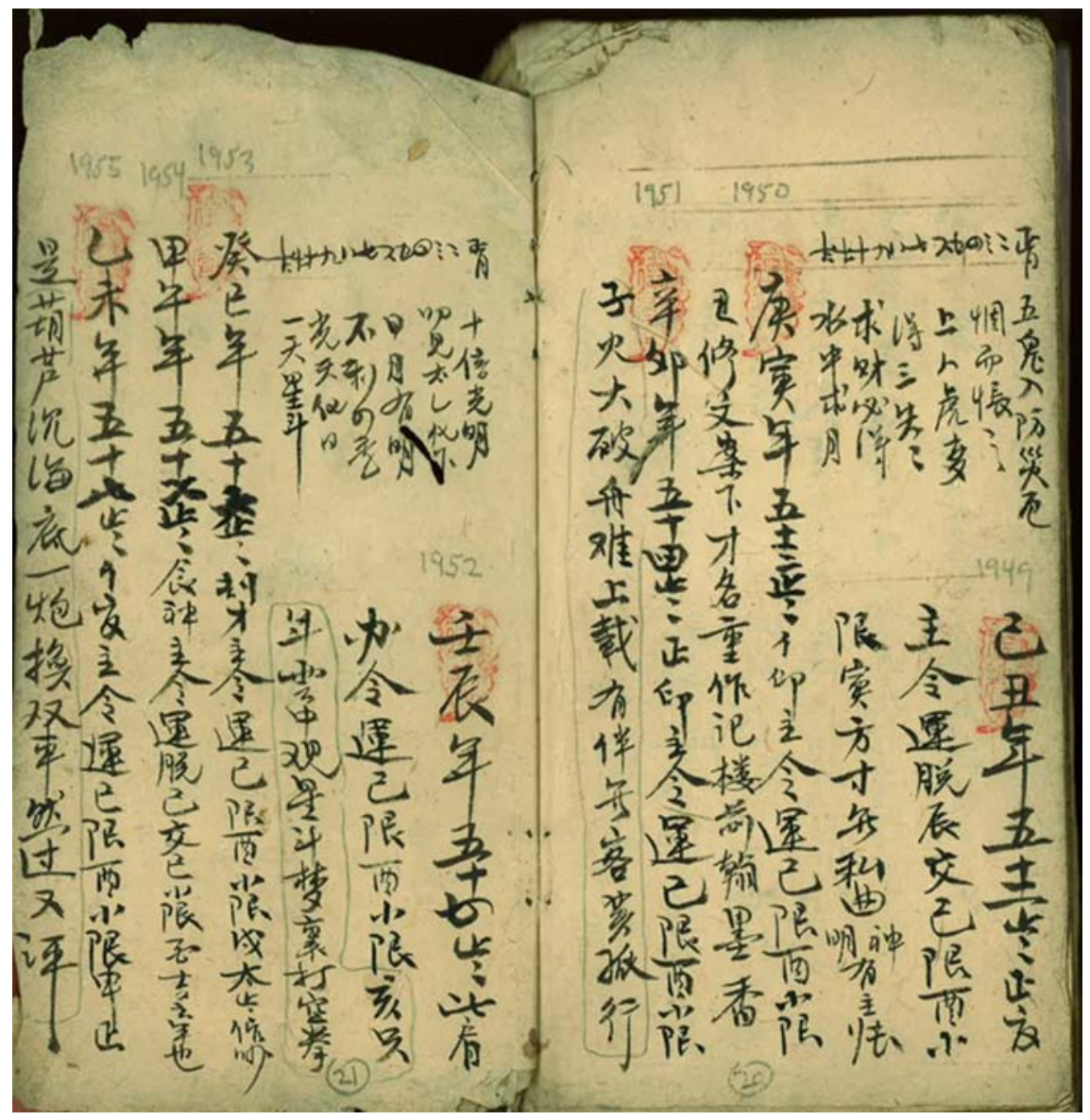

FIGURE 5.13

Astrologer, Pages 20 and 21, The Three-Antis Political Campaign. Predictions for 1952, when our subject was fifty-five years old, were on page 21. The astrologer wrote: "This is a year in which nothing can be accomplished, as if one sits on the clouds looking at the stars, or raises one's fist while in a dream" [Zhinian, yunzhong guanxingdou; mengli, dakongquan 只年, 雲中觀星斗; 夢裡, 打空拳]. This seems to reflect our subject's helplessness in the face of harsh government criticism under the political campaigns then underway.

Рното вY AUTHOR

Such attacks continued against peasants until all land was claimed by the government and eventually transformed into people's communes. Privately owned businesses were likewise expropriated by the government. For the

treatment no better than foreign capitalists. This description is modified and taken from http://en.wikipedia.org/wiki/Three-anti/five-anti_campaigns/, accessed April 8, 2012. 
subject of these predictions, the astrologer's final comment was written to follow 1955, when the subject was fifty-eight years old (p. 21): Zhengshi, hulu chenhaidi; yipao huanshuangche; ranguo youping 正式, 葫蘆沉海底; 一炮換雙 車; 然過又評 [Sink a gourd to the bottom of the ocean; Place a cannon on two chariots. You will be criticized for either]. An empty gourd is light in weight and has air trapped inside, so it is not possible for it to sink to the bottom of the ocean. One cannon on two chariots refers to a move in Chinese chess in which one piece is sacrificed. You will be criticized whatever you do, so you cannot win. The prediction indicates total failure and the impossibility of success, which is likely the position our subject would have been in during the 195 os. $^{15}$

\section{Conclusion: Evaluating the Document}

The importance of the handwritten book discussed in this chapter can be appreciated from two broad perspectives. The first is to view the document as if it were a photograph from a time past. The photograph is static and onedimensional. It lacks specific information about the people who took the photo or appear in it. We do not know the precise year, date, or place of the photo. Nevertheless, it is a concrete image of a moment in the lives of the people associated with the photograph or, in this case, the fortuneteller's book. The information given in it leads us to believe it was written in 1899, to infer that the geographic area in which it was written was the east coast of China, south of Shanghai, and to form an impression of the person whose life was laid out in the text as a member of a family involved in inland river or costal ocean transport.

Photographs, especially those taken with the convenient box cameras of the pre-World War II era, were used a great deal by people who did not leave a detailed written record of their lives. Those people usually took photos of ordinary scenes that had some meaning in their lives. In a similar vein, this fortuneteller's book was not produced by a literary scholar, and most likely

15 Among the American scholars who have examined these large-scale government movements was Gordon Bennett, Yundong: Mass Campaigns in Chinese Communist Leadership (Berkeley: University of California Press, 1976). For an explanation of how the Chinese government prevented business owners from controlling and expanding their own businesses, see Toby Ho, "Managing Risk: The Suppression of Private Entrepreneurs in China in the 1950s," Risk Management: An International Journal, 2, no. 2 (2000). Unfortunately, this article fails to capture the passion and frustration felt by small business owners at the time. 


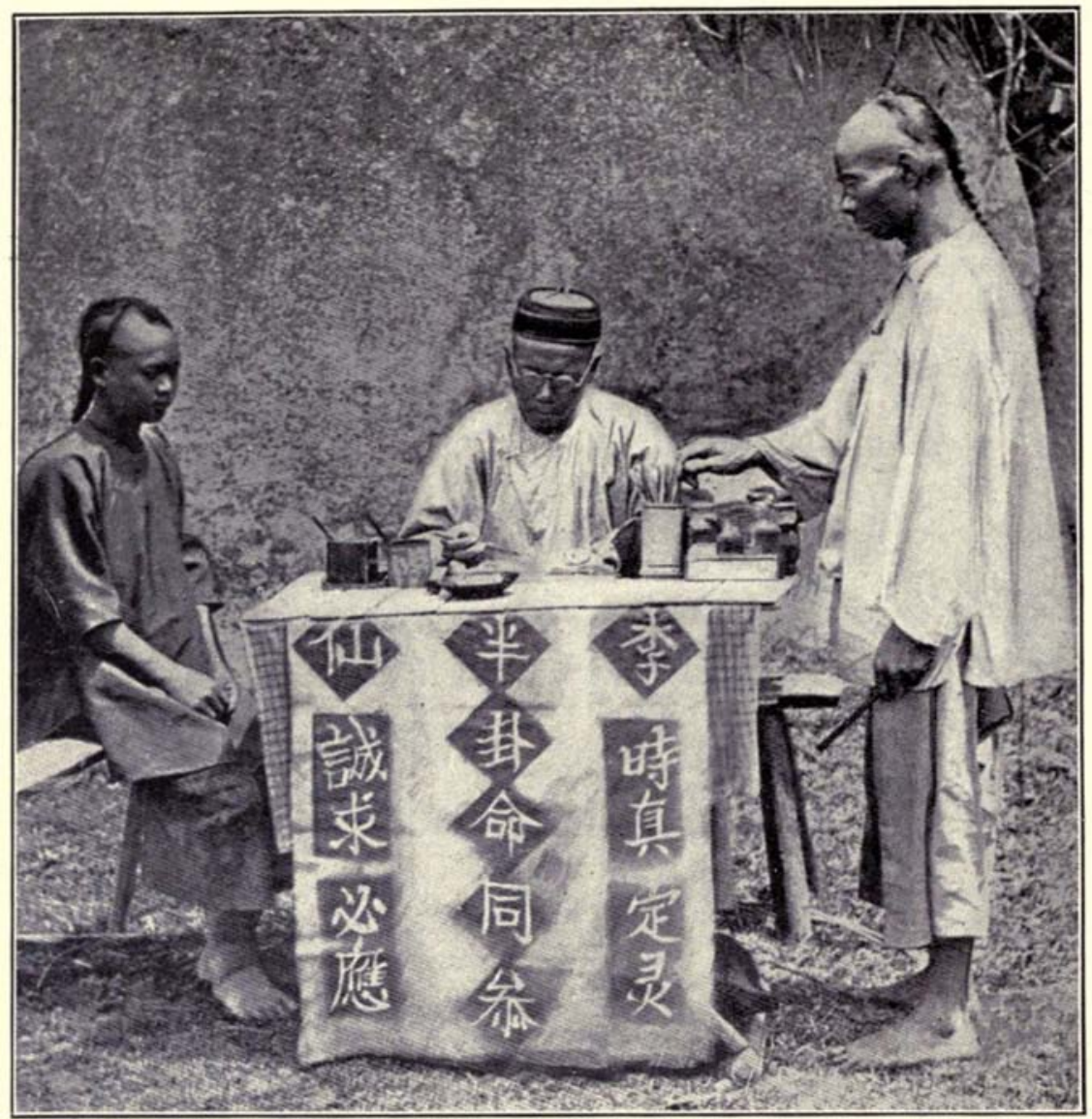

Photo by Mr. Afong]

[Hong-kong.

A CHINESE FORTUNE-TELLER.

FIGURE 5.14

Qing-Era Fortuneteller. The hairstyles, with the Manchu-imposed queue, indicate that this photo was taken during the Qing dynasty. The photo was taken outside, indicating that this fortuneteller wanted to be available to passersby and was offering his services to the general public. The fortuneteller's name was Li Banxian 李半仙 [Li “Almost an Immortal”]. Among the services he advertises, in the center vertical line, are using Trigrams to Determine Your Fortune [Guaming tongcan 卦命同參]. In the line on the left is a phrase often used in religious contexts: "Sincere requests will be answered" [Chengqiu biying 誠求必應], which indicates not just a calculation of fate but an approach to the deities. The photo was taken by Lai Afong 赖阿芳 (1839-189o), who ran a successful photographic studio in Hong Kong from 1895 to the 1940 .

THE PHOTO APPEARED IN C.J. CORNISH, THE STANDARD LIBRARY OF NATURAL HISTORY (NEW YORK: THE UNIVERSITY SOCIETY, 19O7), 136 
its recipient was a person whose work did not involve intellectual or literary pursuits. In lieu of a written record of the subject's life story, we have this fortuneteller's guide, which was no doubt important to the adult who paid for it to be written, most likely the subject's parents. It is equally likely to have been consulted frequently by the subject as he grew up, which is one reason the title page fell off. For the common people of China who were not fully literate in the early 19oos and, so, could not leave a written record, this book acts as the photograph they might have taken if they had had a box camera (which were hard to obtain in China in 1900).

In many ways, looking at a photograph from the past is frustrating, because it can rarely provide all the detailed information we would like to have about it. However, they leave us with very specific and accurate images, and we should appreciate this astrological guide for the information it does tell us.

The second perspective from which to appreciate these handwritten books is to see them as cultural objects created by the common people of China to reflect an aspect of their daily lives. This point of cultural specificity is most likely reflected in the imagery chosen by the fortuneteller to convey his sense of how the subject's future should be viewed. The fortuneteller chose many images dealing with water and boats, partly because the subject was born under the water sign, but equally because this writing was produced in an area of China where waterborne traffic and communication was prevalent and where the winds and rain of the regular typhoons had an impact on the life and health of the people. This is recurring imagery that, when placed in the context of the reference to Wenzhou, gives it added meaning.

Regardless of how accurately we are able to reconstruct the milieu in which this fortuneteller's predictions were constructed and circulated, we should respect the work as a cultural artifact that reflects the culture of the people who created it. Some might say that the accuracy of the predictions in this horoscope is not important, but I doubt that many people would say that about other horoscopes. Certainly, the people in the late Qing who paid to have the book written counted on the accuracy of its predications. When this single work and its specific references are combined with other examples from the same region and historical period, we can begin to get a fuller idea of the people of that time and place. 